\title{
Oenology in the Kitchen: The Sensory Experience Offered by Culinary Dishes Cooked with Alcoholic Drinks, Grapes and Grape Leaves
}

\author{
Fernanda Cosme ${ }^{1, *}$, Teresa Pinto $^{2}$ and Alice Vilela ${ }^{1}$ \\ 1 Chemistry Research Centre (CQ-VR), Department of Biology and Environment, School of Life Sciences and \\ Environment, University of Trás-os-Montes and Alto Douro, 5001-801 Vila Real, Portugal; avimoura@utad.pt \\ 2 Centre for the Research and Technology of Agro-Environmental and Biological Sciences (CITAB), \\ Department of Biology and Environment, School of Life Sciences and Environment, \\ University of Trás-os-Montes and Alto Douro, 5000-801 Vila Real, Portugal; tpinto@utad.pt \\ * Correspondence: fcosme@utad.pt; Tel.: +351-259-350-657; Fax: +351-259-350-480
}

Academic Editor: Robert J. Harrington

Received: 21 June 2017; Accepted: 9 August 2017; Published: 21 August 2017

\begin{abstract}
A good pairing is based on the complementary role of wine on the four important factors of food: components, textures, flavors and colors. Common wine and food examples of food preparation with wine or vine products, such as grapes or vine leaves, exemplify numerous similarities and contrasting characteristics in those four parameters, which we can find in an enjoyable meal. The knowledge of the internal anatomy and composition of both grape berries, which includes the skin, the mesocarp and the endocarp, and vine leaf, which includes the vascular system, parenchymatous mesophyll and epidermis, is essential to know how to develop new, tastier and healthier dishes. An understanding of these ideas is important when defining gastronomic tourism strategies and even local restaurant concepts and ideas. The aim of this review is to provide some insights about the sensory experiences offered by culinary dishes cooked with grapes, vine leaves and wines and other alcoholic beverages like distilled spirits and liqueurs, bearing in mind that wine will be the drink of elation for accompanying such dishes.
\end{abstract}

Keywords: wine; alcoholic drinks; grapes; vine leaves; sensory experience; cooking

\section{General Introduction}

All gastronomies are in continuous evolution and are a fusion of unique and identifiable products and traditions. Classic wine and food examples of cooking with wine or vine products illustrate many of the similarities and contrasting characteristics in components, texture, flavors and color that we can find in a pleasant meal [1]. An understanding of these concepts can be appreciated when defining gastronomic tourism strategies and local restaurant concepts [2].

Subconsciously, humans prefer sweet flavors because these are a source of energy, and they avoid bitter and sour tastes/flavors as these are related to toxicity and danger [3]. A new concept for creating healthy desserts without the addition of fat or sugar has been developed by Alija and Talens [4] involving two basic principles: (i) taking advantage of the natural sweetness of fruits and (ii) never forgetting the surprise of provocation. Grapes can be used as fresh fruit (table grape) and processed fruit such as jam, grape juice, wine, jelly, molasses and raisins. Grapes are considered as a rich source of phenolic compounds and have tremendous potential for use in the development of such products [5], thus making desserts, or even main courses, awesome culinary and sensory experiences.

The grape berries present a spherical symmetry with three different tissue strata: outer exocarp (the dermal system or skins), the median mesocarp (thin-walled parenchyma) and the inner endocarp 
(crystal-containing cells and an inner epidermis) [6]. Sugars (glucose, fructose and sucrose), organic acids (malic, tartaric and citric acid), flavor compounds (volatiles and non-volatiles) and phenolic compounds (phenols, anthocyanins and flavonols) are present at different percentages in each grape berry strata, anthocyanins being the phenolic compounds responsible for the red skin color in red grape varieties [7].

For many years, wine has not been the only product of economic importance that the vine provides for use in the kitchen. Grape leaves (or vine leaves) have been used in Greek cooking since ancient times, and abelofylla yemista (dolmades, stuffed grape leaves) are classics in Greek homes and restaurants around the world. A similar dish is made in Turkey, and it is called "sarma", which means "wrapped" in Turkish [8]. Vine leaves, briefly blanched or brined with salt, are rolled around a filling made of rice. Vine leaves can be used fresh from the vine in late spring and early summer, when tender leaves are plentiful, and they can be stored for use at other times. Vine leaves are a waste product from the grapevine, frequently rejected by grape growers, but are a rich source of phenolic compounds and other therapeutic compounds [9].

The Vitis vinifera leaf is a typical mesomorphic leaf [10], commonly large, alternate, petiolate with palmate lobes that may appear to be shaped like a hand. The differences among the upper surface coloration (green-dark) and the lower surface (clear green) is clear and due fundamentally to the uneven distribution of the chlorophyll pigments in the two layers, a greater quantity being present in the upper layer.

The grapevine is as old as time and due to its notable regenerative properties has become known as a symbol of life, frequently referred to as the tree of life. Wine is the major product, which has been reported in the oldest historical chronicles and writings [11]. However, wine is not only used for dinking; some cooking literature focused on traditional, as well as innovative food preparations with wine or beer as an ingredient has been published [12,13]. Wine can be associated with food in three dimensions: complementary, social meanings and lubrication effect. Red wines also provide new colors to the dishes. Wine color is one of the most easily identifiable characteristics of wines, which can be red, white or rose. The color attribute is important in wine tasting and in gastronomy. For example, red wines with a deeper red color when used in culinary tinge the food with the pigments they carry, namely anthocyanins and tannins that form pigmented polymers in association with the anthocyanins to offer the stable pigments essential to giving red wine color its long-term color stability [14]. The use of alcoholic beverages in cooking has the purpose of adding flavor to the food but it may also change the food texture. Cooks use wines, beers, distilled spirits and even rice wine [15] as ingredients in a broad range of dishes, from savory soups, sauces and stews to sweet desserts and sorbets. They contribute distinctive flavors, often including acidity, sweetness and savoriness, from glutamate [16], and the aromatic dimension provided by alcohol and other volatile substances [17]. Nevertheless, some wine qualities can be a challenge in the kitchen, including the astringency and bitterness of red wines. The alcohol itself also provides a third kind of liquid (in addition to water and oil), into which flavor and color molecules can be extracted and dissolved, as well as reactive molecules that can combine with other substances in the food to generate new aromas and greater depth of flavor. While large amounts of alcohol tend to trap other volatile molecules in the food, small traces boost their volatility and so intensify aroma [18].

Therefore, the aim of this review is to provide some insights about the sensory experiences offered by culinary dishes cooked with grapes, vine leaves, wine and other alcoholic drinks bearing in mind that wine will be the drink of elation in accompanying such dishes.

\section{The Use of Grape Berries in Culinary Dishes}

\subsection{Grape Berries' Composition}

Red and white grapes' chemical compositions are shown in Table 1. One of the main compounds of grapes is sugars in the form of glucose and fructose. The sugar concentration of 98 grape varieties 
analyzed by Liu et al. [19] presented $46-123 \mathrm{mg} / \mathrm{mL}$ of glucose and $48-131 \mathrm{mg} / \mathrm{mL}$ of fructose. Grape berries store glucose and fructose in identical quantities at a relatively constant rate during ripening [20].

About $90 \%$ of the organic acids in grapes are L-tartaric and L-malic acids [21,22]. Minor quantities of citric, succinic, lactic and acetic acids are also existent in grapes [23].

Nitrogen compounds present in grapes comprise ammonium cations and organic nitrogen compounds such as amino acids, hexose amines, peptides, nucleic acids and proteins [24]. The main grape free amino acids include proline (up to $2 \mathrm{~g} / \mathrm{L}$ ), arginine (up to $1.6 \mathrm{~g} / \mathrm{L}$ ) and, to a lesser extent, alanine, aspartic acid and glutamic acid [25]. According to Hernandez-Orte et al. [26], the amino acids contribute to the wine aroma, taste and appearance.

Phenolic compounds present in grapes are mainly in the grape berries' skins and seeds [27] and also in grape stems [28]. These compounds are essential because they are responsible for sensory characteristics, like color and astringency. The phenolic compounds present in grapes include non-flavonoids and flavonoids. The non-flavonoid compounds comprise phenolic acids divided into hydroxybenzoic acids and hydroxycinnamic acids, but also other phenol derivatives such as stilbenes. Non-flavonoid phenolic compounds incorporate hydroxycinnamates acids, hydroxybenzoic acids and stilbenes. Common hydroxycinnamic acids are $p$-coumaric acid, caffeic acid, sinapic acid and ferulic acid since the most common hydroxybenzoic acids are gallic acid, gentisic acid, protocatechuic acid and $p$-hydroxybenzoic acid, which are mainly found in their free form $[29,30]$. For flavonoid phenolic compounds, such as flavonols, flavanols and anthocyanins [31], flavonols are the most abundant phenolic compounds in grape skins [32], while grape seeds are rich in flavan-3-ols [28]. The average quantity of the total phenolic compounds in different grape fractions varied from $2179 \mathrm{mg} / \mathrm{g}$ gallic acid equivalent in seeds to $192-375 \mathrm{mg} / \mathrm{g}$ gallic acid equivalent in skins. In addition, it is also possible to find low quantities of phenolic compounds in pulps $(23.8 \mathrm{mg} / \mathrm{g}$ gallic acid equivalent) [33]. The phenolic compounds responsible for the red color of the grape berries are the anthocyanins; these phenolic compounds are glycosylated derivatives. In $V$. vinifera grape varieties, the 3-monoglucosides are the main anthocyanins where glucose can be acylated by acetic, $p$-coumaric and caffeic acid $[34,35]$. Polymerization of flavan 3-ol units, $(+)$-catechin and $(-)$-epicatechin and their gallate esters originated oligomers and polymers named proanthocyanidins. Seeds enclosed procyanidin of (+)-catechins, (-)-epicatechin and epicatechin gallate units, while grape skin enclosed procyanidins and prodelphinidins frequently based on (-)-epicatechin and epigallocatechin units [36,37]. The total amount of procyanidins ranged from 1.7-4.4 g/ $\mathrm{kg}$ of berries in skin, $1.1-6.4 \mathrm{~g} / \mathrm{kg}$ in seeds and $0.2-1 \mathrm{~g} / \mathrm{kg}$ in pulp [38].

Grape flavor compounds could be divided into volatile and non-volatile compounds. Volatile flavor compounds that were isolated from grapes are monoterpenes in Muscat grape varieties [39] and methoxypyrazines in Cabernet Sauvignon, Sauvignon Blanc and Semillon grape varieties [40]. 
Table 1. White and red grape varieties' chemical composition.

\begin{tabular}{|c|c|c|c|c|c|c|c|c|}
\hline \multirow{3}{*}{ Compound } & \multicolumn{8}{|c|}{ Grape Variety } \\
\hline & \multicolumn{4}{|c|}{ Red Grape Varieties } & \multicolumn{4}{|c|}{ White Grape Varieties } \\
\hline & Berry & Skin & Seed & Reference & Berry & Skin & Seed & Reference \\
\hline Sucrose (g/L) & $1.7-4.4$ & & & {$[41]$} & $1.6-3.7$ & & & [41] \\
\hline \multirow{2}{*}{ Glucose $(\mathrm{g} / \mathrm{L})$} & $81.6-93.7$ & & & [41] & 77.3-93.9 & & & [41] \\
\hline & $93.6-107.0$ & & & [42] & $86.4-104.9$ & & & [42] \\
\hline \multirow{2}{*}{ Fructose $(\mathrm{g} / \mathrm{L})$} & $79.1-95.9$ & & & [41] & $80.9-102.1$ & & & [41] \\
\hline & $80.4-94.1$ & & & [42] & $73.1-88.5$ & & & [42] \\
\hline Total sugar $(\mathrm{g} / \mathrm{L})$ & $181.2-198.9$ & & & [42] & $163.5-197.8$ & & & [42] \\
\hline \multirow{2}{*}{ Tartaric acid $(\mathrm{g} / \mathrm{L})$} & $4.3-4.9$ & & & [41] & $5.0-6.2$ & & & [41] \\
\hline & $3.8-5.2$ & & & [42] & $4.8-5.0$ & & & [42] \\
\hline \multirow{2}{*}{ Malic acid $(\mathrm{g} / \mathrm{L})$} & $2.2-2.9$ & & & [41] & $1.5-1.9$ & & & [41] \\
\hline & $3.0-3.1$ & & & [42] & $2.8-3.6$ & & & [42] \\
\hline Citric acid $(\mathrm{g} / \mathrm{L})$ & $0.3-0.4$ & & & [42] & $0.2-0.3$ & & & [42] \\
\hline \multirow{2}{*}{$(+)$-Catechin $(\mathrm{mg} / \mathrm{kg} \mathrm{FW})$} & $197-515$ & & & [43] & $70.3-659.1$ & & & [43] \\
\hline & $39.2-533$ & & & [44] & $61.0-481$ & & & [44] \\
\hline (-)-Epicatechin (mg/kg FW) & $63.5-467.3$ & & & [44] & $84.3-144$ & & & [44] \\
\hline \multirow{3}{*}{ Procyanidin B1 } & $13.39-15.95^{\mathrm{a}}$ & $8.4-22^{c}$ & $74-170^{\text {e }}$ & {$[45,46]$} & $2.4-3.3^{b}$ & $12-48^{c}$ & $200-620^{d}$ & {$[41,46]$} \\
\hline & $4.2-7.2^{\mathrm{b}}$ & $0.09-0.26^{\mathrm{d}}$ & $5.3-5.92^{\mathrm{d}}$ & {$[42,47,48]$} & & $1.1-1.9^{\mathrm{d}}$ & $0.2-2.0^{\mathrm{d}}$ & [49] \\
\hline & & & $1.38-3.58^{\mathrm{d}}$ & {$[47]$} & & & & \\
\hline \multirow{3}{*}{ Procyanidin B2 } & $5.74-10.39^{a}$ & $0.75-2.2^{c}$ & $21-41^{\mathrm{e}}$ & {$[45,46]$} & $0.3-2.0^{\mathrm{b}}$ & $0.06-0.2^{\mathrm{d}}$ & $15-33^{\mathrm{e}}$ & {$[42,46,49]$} \\
\hline & $1.9-4.3^{\mathrm{b}}$ & $0.011-0.020^{\mathrm{d}}$ & $24-30^{d}$ & {$[42,47,48]$} & & & $3.8-5.6^{\mathrm{d}}$ & [49] \\
\hline & & & $1.75-5.23^{\mathrm{d}}$ & [47] & & & & \\
\hline \multirow{3}{*}{ Procyanidin B3 } & & $16-39^{c}$ & $43-64^{\mathrm{e}}$ & [46] & & $21-37^{c}$ & $39-59$ e & [46] \\
\hline & & $0.013^{\mathrm{d}}$ & $5-7.3^{\mathrm{d}}$ & {$[47,48]$} & & $0.2-0.3^{\mathrm{d}}$ & $0.9-1.8^{\mathrm{d}}$ & [49] \\
\hline & & & $0.45-0.96^{\mathrm{d}}$ & [47] & & & & \\
\hline \multirow{3}{*}{ Procyanidin B4 } & & & $33-80^{\text {e }}$ & [46] & & $0.04^{\mathrm{d}}$ & $53-95^{\mathrm{e}}$ & {$[46,49]$} \\
\hline & & & $8-12.24^{\mathrm{d}}$ & [47] & & & $2.5-2.9^{\mathrm{d}}$ & [49] \\
\hline & & & $0.65-2.57^{\mathrm{d}}$ & [46] & & & & \\
\hline
\end{tabular}


Table 1. Cont.

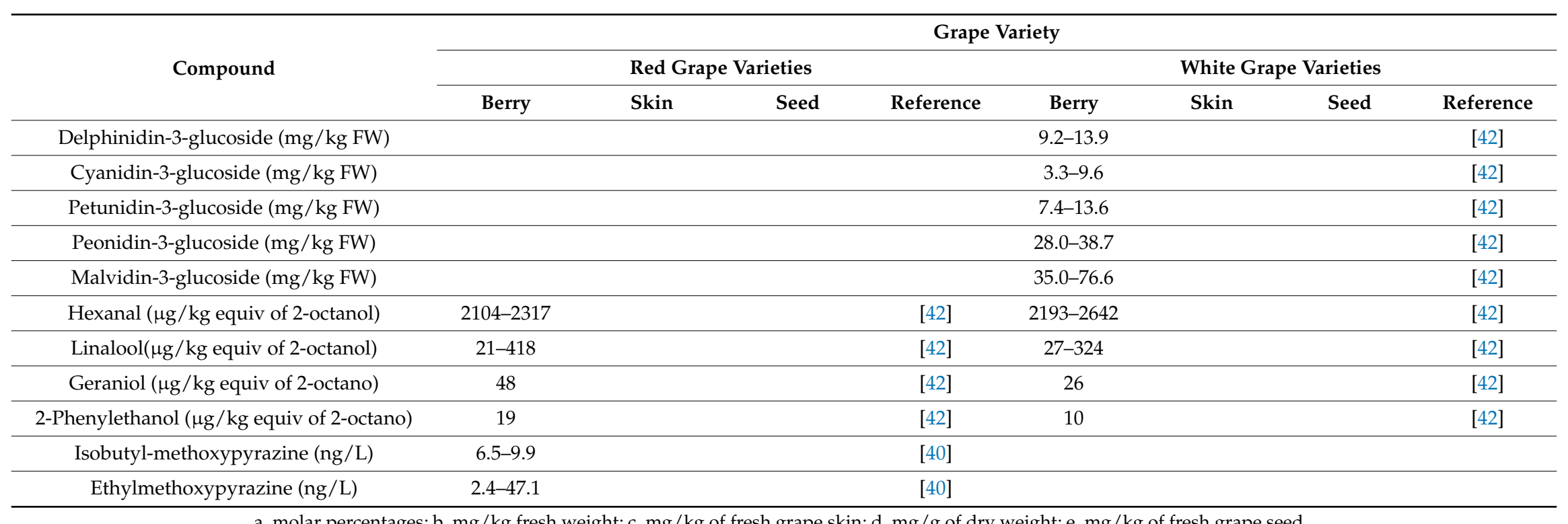

a, molar percentages; $\mathrm{b}, \mathrm{mg} / \mathrm{kg}$ fresh weight; c, $\mathrm{mg} / \mathrm{kg}$ of fresh grape skin; $\mathrm{d}, \mathrm{mg} / \mathrm{g}$ of dry weight; $\mathrm{e}, \mathrm{mg} / \mathrm{kg}$ of fresh grape seed. 


\subsection{Grape Berries' Anatomy and Histology}

Grape (Vitis vinifera L.) is one of the major crops worldwide based on cultivated hectares and economic value [50]. Grapevines comprise vegetative organs (roots, trunk, cordon, shoots, leaves and tendrils) and reproductive organs (clusters with flowers or berry fruit). All organs are interconnected through the vascular system comprising the xylem for water and nutrient transport and the phloem to assimilate transport. The roots form the plant-soil interface, while the trunk, cordons and shoots of a vine form its stem. The shoots carry the leaves, buds, tendrils and clusters. Leaves are arranged in spiral phyllotaxy in juvenile vines and in alternate phyllotaxy in mature vines. Buds are young, compressed shoots embedded in leaf scales. Tendrils and clusters are modified shoots. After fertilization, the flower pistil develops into the berry fruit [51].

Berry size and quality depend mainly on water, sugars (glucose and fructose), organic acids (malic and tartaric acids), phenolic compounds (anthocyanins and tannins) and aroma precursors. Many advances have been made in understanding how grape berry develops and the chemical compounds that are important for winemaking [52]. Such knowledge is equally important when it is intended to make other uses of grape berries, other than in the manufacture of alcoholic beverages. Indeed, the majority of fruit production is processed into wine, but significant portions are consumed fresh, dried into raisins, processed into nonalcoholic juice, distilled into spirits or used directly in the kitchen [53]. The use of grape berries in cooking is currently a new reality. Thus, knowing the anatomy of the grapes from the perspective of evaluating the sensory characteristics of each one of its components is important.

Berries represent an integrated, systematic structure of tissues consolidated almost in a spherical symmetry. These constituents are tastefully stratified in three different tissue strata: outer exocarp (the dermal system or skin), the median mesocarp and the inner endocarp (Figure 1). Collectively, these strata include the pericarp in whose locules reside two to four seeds, two in each locule. Of these three tissues, the translucent and hydrated mesocarp composes the greater portion (85-87\%) of the berry's spherical volume [6]. The chemical composition of each of these tissue types differs, which strongly influences final grape and grape product quality.

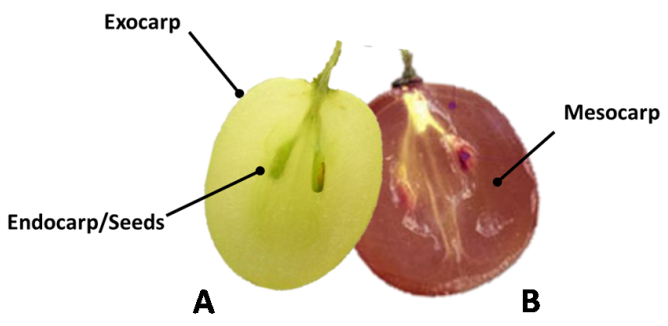

Figure 1. Similar structure of the white (A) and red (B) ripe grape berries (adapted from Rosa [54] and Agrisoil Research [55]).

The exocarp or skin of the grape berry forms a heterogeneous region constituted by cuticle, epidermis and hypodermis [56]. According to Wilson et al. [57], grape skin ranges from 5-18\% of the fresh weight of the fruit. It consists of 6-8 cell layers, the outer wall of the epidermis being protected by a waxy layer called the cuticle (Figure 2). The cuticle, secreted by epidermal cells, is a continuous layer whose thickness varies depending on the variety, protecting the fruit from drying, as well as providing a barrier to fungi and bacteria. 


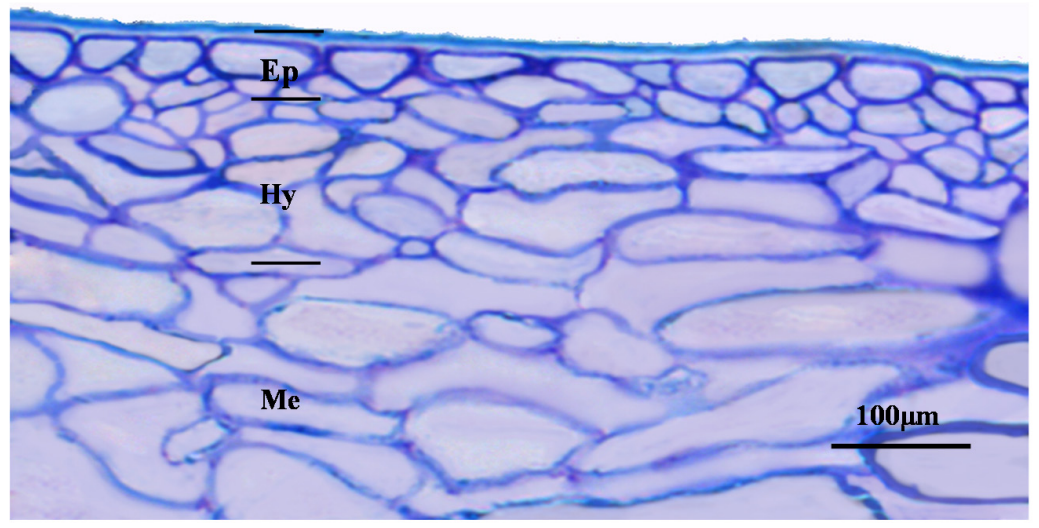

Figure 2. Traverse section of grape berry skin at maturity: epidermis and cuticle (Ep), hypodermis (Hy), mesocarp (Me).

Contrasting some other plant surfaces, grape berry skin does not contain a significant number of functional stomata. Therefore, water loss happens frequently through the waxy cuticle, a relatively slow process. One consequence of this physiology is that grape berries do not dissipate heat well via water evaporation. Another consequence is that grape berries are not well able to shed excess water quickly. Hence, they are more susceptible to splitting compared to some other fruits [58], and this is an important feature when grapes are cooked.

The outermost part, constituted of one or two layers of tangentially-elongated cells whose thickness varies depending on the grape variety, is considered to be the epidermis. The four or five cell layers immediately under the epidermis are considered to be the hypodermis. This protective layer comprises two distinguishable regions: an outer region with rectangular cells and an inner region with polygonal cells [56].

In the grape berry, the exocarp and mesocarp tissues diverge in orientation of cell expansion, as well as in the timing of this expansion [59]. Exocarp cell size in these layers is clearly minor compared to in the mesocarp cells, which supports the cell size being an important criterion for identifying a hypodermis [60]. Therefore, immediately below the hypodermis, there are polygonal cells with very thin, distended cell walls that are considered to be the mesocarp.

The mesocarp grape berry cells are characteristically larger and rounder than the cells that make up the skin. These cells comprise large vacuoles, which are the primary sites for the accumulation of sugars, organic acids, aromas, flavors, ions and water, during grape berry ripening. The grape berry vacuole cells have attracted attention principally because their storage function contributes directly to fruit quality [52].

Grape berry consistency depends on skin and pulp cell wall thickness. Commonly, table grape varieties yield plump, thin-skinned grapes (the mesocarp having thick cell walls), whereas winemaking varieties have tough skins and juicy pulp (pulp with thin cell walls) [56].

\subsection{Cooking with Grapes, Sensory Aspects}

As was mentioned before, grapes can be used as fresh fruit or processed into products such as jam, grape juice, jelly, molasses, wine and raisins. Grapes are a rich source of polyphenolic compounds and antioxidants including vitamins, flavonoids and phenols $[15,61]$.

The color of processed grape products is a factor of quality. The skin of red grapes is typically dark blue or purple. The traditional jam production process uses pectin as the gelation agent, which needs high temperatures for the gel formation. The loss of color pigments during jams processing is due to the temperature increase (over $100{ }^{\circ} \mathrm{C}$ ) [62], and of course, color is an important attribute in jams. 
Pop et al. [63] aimed to evaluate the quality and the effect of jam processing of Concord black grapes without added sugar. At the end of the work, they found that the concentration of fructose, sucrose and glucose ranged from $17-17.3^{\circ}$ Brix and the refractometric measurement of SDS (soluble dry substance) passed the minimum quantity of $67 \%$, which guarantees the conservability of the product. The highest quantity of polyphenols and antioxidant capacity was found in the jam compared to in the initial grapes, which is probably due to the concentration of grape pulp during the jam production.

\section{Grape Leaves Textural, Histological Characteristics and Composition}

At the beginning of the 21st Century, one of the key issues of the processing industries has been the use of secondary resources. In winemaking, the key wastes are sweet and fermented grape pomace, yeast lees and racking sludges, grape seed and others. One of the novel guidelines is the use of vegetative parts of the vine plant of a seasonal nature. These primarily comprise leaves, which have a large reserve of antioxidants and other appreciated substances, such as catechins, flavonoids, tannins, malic, silicic, citric, tartaric and succinic acids and resveratrol [64].

A study carried out by Katalinic et al. [65] in grape leaf extracts showed that they are rich in total phenolic compounds, that this richness is dependent on the harvesting date of the leaves, the average concentration of total phenols in September leaves being $3339 \mathrm{mg}$ GAE/L, around 30\% higher compared to May leaves' extract (2911 mg GAE/L) due to the significant increase of total flavonoids, especially the catechin fraction. Conversely, the concentration of non-flavonoid phenolic compounds was not dependent on the harvest date of the leaves (1745 mg GAE/L for May leaves' extracts and $1759 \mathrm{mg}$ GAE/L for September leaves' extracts). Güler and Candemir [66] studied the total phenolic and flavonoid content of fresh leaves commonly consumed in Turkey. This author determined a total phenolic content from $9.72-14.22 \mathrm{mg} / \mathrm{g}$ in fresh leaves and total flavonoid contents from $5.08-7.22 \mathrm{mg} / \mathrm{g}$ in fresh leaves, (+)-catechin, (-) epicatechin, gallic acid, caffeic acid and vanillic acid being detected in all fresh leaves. Radovanovićn et al. [67] and Dani et al. [68] also studied the phenolic composition of grape leaves, as shown in Table 2.

Table 2. Grape leaves' phenolic composition.

\begin{tabular}{ccc}
\hline Compounds & Grape Leaves & Reference \\
\hline Total phenols (mg Gallic acid equivalent/g) & $18.32-42.65$ & {$[67]$} \\
& $15.1-23.8$ & {$[43]$} \\
\hline Hydroxycinnamoyl tartaric esters (mg caffeic acid equivalent/g) & $9.06-12.73$ & {$[68]$} \\
\hline Flavanols (quercetin equivalent/g) & $10.12-15.84$ & {$[67]$} \\
Caftaric acid (mg/kg) & $1.87-3.89$ & {$[43]$} \\
\hline Catechin (mg/g raw extract) & $391-914$ & {$[43]$} \\
Quercetin (mg/g raw extract) & $3.64-4.30$ & {$[68]$} \\
Rutin (mg/g raw extract) & $5.86-6.74$ & {$[68]$} \\
Kaempferol (mg/g raw extract) & $44.90-55.75$ & {$[68]$} \\
& $1.37-1.43$ & {$[68]$} \\
\hline
\end{tabular}

Grape leave extracts are also rich in volatile compounds, as shown by Fernandes et al. [69], who studied the volatile composition of vine leaves' infusions prepared from vine leaves collected 30 and 60 days after grape harvest from two Portuguese red grape varieties (Touriga Nacional and Tinta Roriz). They also showed that the volatile compounds existing in vine leaves infusions were dependent on the harvest time, with a significantly higher volatile concentration in vine leaves collected after 30 days of harvesting. These authors identified twelve volatile compounds in vine leaves' infusions (6-methyl-5-hepten-2-one, 1-undecene, Z-citral, cedrenol, DL-limonene, 2,4-hexadien-2-ol, benzaldehyde, heptane-1,2,4,6-tetraene, cyclohexene 1-methyl-4-(1-methylethyl), 1,6-octadien-3-ol, 3,7-dimethyl, 5,9-undecadien-2-one-6,10-dimethyl-(5E) and $\alpha$-cedrol). This study showed that the harvesting date was more important for the vine leaves' infusion volatile profile than the vine leaf grape cultivar [69]. 
In some countries around the world (mainly in Turkey, Greece and Middle Eastern countries), the inclusion of vine leaf in the human diet used as an ingredient for the preparation of dishes [8] is already a reality, endowing the consumer with health benefits.

According to Salt et al. [8], grapevine leaves can be consumed fresh or in preserved forms such as frozen or in brine solutions and preserved in cans or jars. However, in order to become edible, they must be processed by culinary treatments: blanching, boiling or steaming. Information regarding grapevine leaves' alterations during the culinary and preservation procedures is very limited. Some varieties are more suitable to be consumed in fresh form, while others could be submitted to preservation treatments and consumed later. The knowledge of the leaves' texture and ultrastructure proves to have great importance to assess the most suitable varieties to be submitted to the culinary process.

Some factors such as grape ripeness and variety can considerably affect the grape quality. The same seems to happen with the vine leaf. Indeed, old leaves are very hard; it is difficult to make a stuffed dish from leaves. Consequently, young leaves (immature) are selected for this purpose [69]. Gokturk et al. [70] reported that harvesting leaves at the beginning could decrease the quality of canned food. In addition, thick, hairy, lobed leaves are usually excluded by consumers.

Leaf anatomical characteristics are main functional and adaptive traits determining plant capacity to thrive in specific environments, in particular since these traits also have important implications in the photosynthesis process [71] in which green plants use energy from the Sun to transform water, carbon dioxide and minerals into oxygen and organic compounds.

The Vitis vinifera leaf is a typical mesomorphic leaf [10] with a dorsoventrally-flattened lamina, where distinction among the upper surface coloration (green-dark) and the lower surface (clear green) coloration is evident. Although there are some differences in the morphological and anatomical characteristics between the cultivars of Vitis vinifera [72-74], the leaves of this species are commonly large, alternate, petiolate with palmately lobed, which may appear to be shaped like a hand (Figure 3).

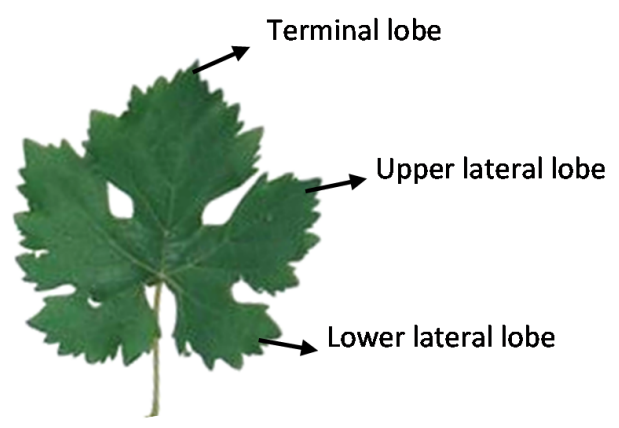

Figure 3. Vine grape leaf type structure.

On the leaves internal anatomy, the leaf consists of a vascular system (it has several major veins, all of which depart from the same point at the base of the limbus), parenchymatous (mesophyll) and mechanical supporting tissues and also dermal tissues in the form of a persistent epidermis. Because of the usually flat leaf blade, the epidermis is separated between the leaf margins into upper (adaxial surface) and lower (abaxial surface). In this way, the leaf mesophyll anatomy of grapevine cultivars evidences an adaxial and an abaxial epidermis formed by a single layer of cells (Figure 4). Their cells are chloroplast-free and have straight anticlinal walls, forming a compact layer without intercellular spaces. The outer cellulose wall rarely contains lignin. The epidermis has to protect the leaf against uncontrolled water loss and against damage by environmental factors, such as bending of the leaf blade by wind or the attack of microorganisms. This is achieved by the compact arrangement of cells and by incrustation of the outer wall with cutin, constituting a special layer, the cuticle [75]. The thickness of the cuticle often corresponds with the xeromorphic degree of the leaf. Thus, cultivars grown in drier environments reveal thicker cuticles [76]. 
The stomata are fundamentally present in the lower epidermis surface. Several studies reported different values for transverse epidermal cell surface area and epidermal thickness for the same cultivar [73]. These differences seem to indicate that ecological conditions may influence grapevine anatomical features [74].

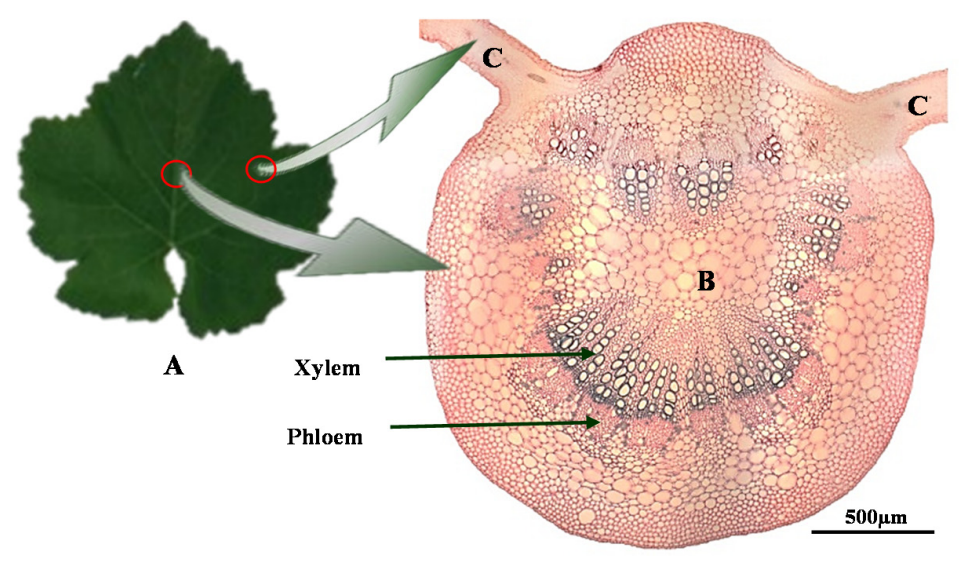

Figure 4. Vitis vinifera leaf (A); main vein (B); mesophyll (C).

The mesophyll photosynthetic tissue consists of palisade and spongy parenchyma. The vine mesophyll leaves are heterogeneous and asymmetrical due to the presence of palisade parenchyma in the upper surface and spongy parenchyma in the lower surface (Figure 5).

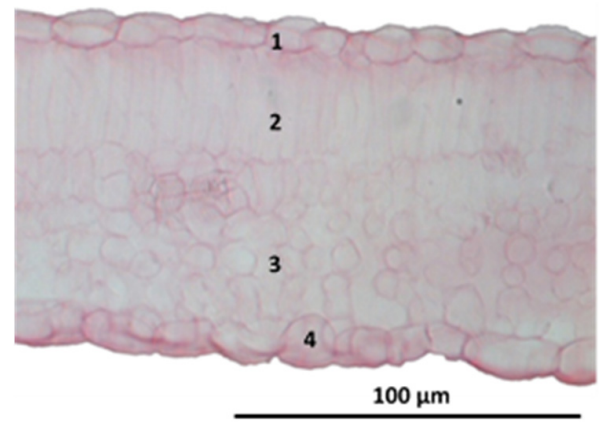

Figure 5. Cross-sections of Vitis vinifera, cultivar Touriga Nacional, leaf mesophyll. 1, Upper epidermal cells; 2 , palisade parenchyma; 3 , spongy parenchyma; 4, lower epidermal cells.

The intensity of light and its quality also interfere in the phenotypic expression of the leaves [77], and this is evident in the vine leaves. Consequently, the internal leaf anatomy differs. In the leaves that develop in a better position towards light, the mesophyll becomes thick, and the proportion of the palisade parenchyma increases in relation to the spongy parenchyma. Therefore, the palisade parenchyma has rod-shaped cells with a few intercellular air spaces, a great deal of chloroplasts, arranged in 1-2 layers, or up to three, the leaf being oriented toward the north or south [78].

The spongy tissue is characterized by wide lacunas. Indeed, the spongy parenchyma presents isodiametrical cells of an irregular contour, and its content is markedly cytoplasmic vacuolar, poor in chloroplasts. The intercellular spaces are much larger and in higher numbers compared to the palisade parenchyma (Figure 5). A rich network of veins facilitates the export of assimilates.

The grapevines leaves show palmate venation. The larger diameter veins often have a mass of fibers connecting them to the lower and upper epidermis, called bundle sheath extension. The fibers provide rigidity to the leaf [75].

The arrangement of the xylem (specialized in the transport of water) and the phloem (specialized in the transport of organic substances formed during photosynthesis) is centric in major veins; thinner 
veins have collateral bundles where the xylem elements are facing the inside and the phloem elements facing the outside of the leaf.

\section{The Use of Grape Leaves in Gastronomy}

Sarma (Figure 6), which symbolizes one of the most general feasting dishes of Middle Eastern and south-eastern European gastronomies, is a culinary dish made with cooked grape vine leaves rolled around a filling made from rice and/or minced meat, probably vegetables and seasonings [79].

The term sarma, meaning "wrapped" in Turkish, defines leaves (raw, or more often briefly blanched or kept in salt brine) rolled around a filling made of rice, bulgur and/or minced meat, possibly vegetables and seasonings (especially onion) and gently cooked (stewed or boiled) in a pot and generally consumed warm (with meat) or cold (without meat) [79]. This culinary dish has long represented (at least for four centuries) a crucial festivity dish in many areas of the Ottoman Empire and was present on the menus of palaces and official residences (konaks), where it was prepared as a main course or as a side dish to a main course meat meal [80]. These dishes may be accompanied by wine made from the same grapes from which the leaves where collected. Indeed, the leaves do have some of the taste, and even the smell, of grapes.

V. vinifera leaves have also been employed to produce dietary ingredients [81] or in the formulation of dietary antioxidant supplements [82].

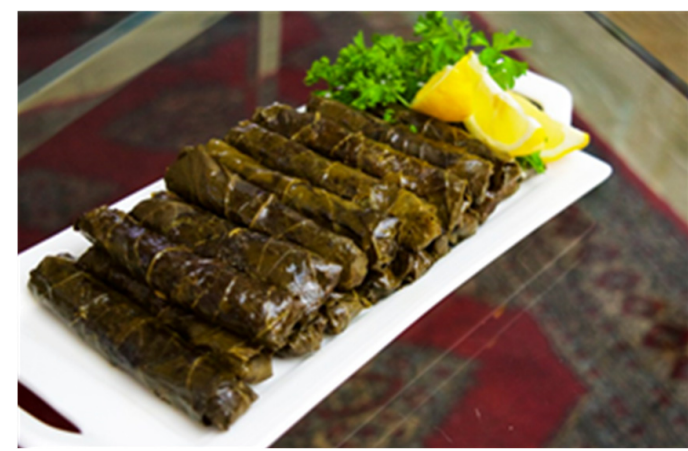

(A)

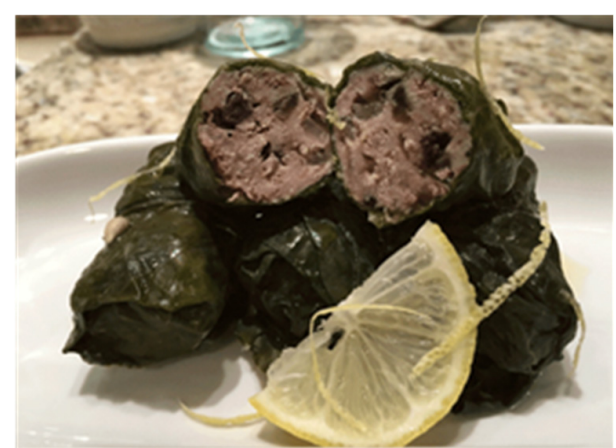

(B)

Figure 6. 'Sarma' (SAR'-mah) and 'Dolma' (dole-MAH') in Turkish cooking. 'Sarma' means 'wrapped thing ((A) cooked spicy rice wrapped in grape leaves). 'Dolma' means 'stuffed thing'; ((B) grape leaves rolls stuffed with meat). These are general terms used for many varieties of vegetables and leaves, including grape leaves, rice fillings and stuffed with meat.

\section{Cooking with Wine}

In the kitchen, wine has three key uses: as a marinade constituent, as a cooking liquid and as a flavoring in a final dish. Wine's function in cooking is to intensify, enhance and accent the flavor and aroma of food. As with any seasoning used in cooking, care should be taken in the quantity of wine applied; too little is trivial, and too much will be overshadowing. Neither extreme is desirable. A small amount of wine will improve the flavor of the dish [83].

There are physical interactions between the food or beverage components; in this case, the wine matrix influences the release of volatile compounds [84] and multi-modal interactions resulting from the cognitive or psychological integration of the anatomically independent sensory systems [85].

\subsection{Sensory Characteristics Perceived in Wine Cooking Dishes}

\subsubsection{Alcohol Hot and Sweet Sensations}

Alcohol, mainly ethanol, is the most abundant volatile compound in wines (Table 3). It modifies both the sensory perception of wine aromatic attributes and the detection of volatile compounds [86]. 
Consequently, alcohol is important for wine sensory sensations, but also their interaction with the meal components, such as aromas/flavors [86], influencing the sensation of viscosity and body [87] and our perceptions of the astringency sensation, sour and sweet tastes, aroma and flavor [88].

According to Joachim and Schloss [83], alcohol improves the flavor of cooked dishes. The wine alcohol does not enhance the flavor of dishes so much as it makes other ingredients taste better. It helps release flavor molecules in foods and assists in dissolving fats. In fact, in terms of health issues, a moderate alcohol intake does not have any substantial consequence on the human phospholipid and fatty acid composition, but the fat-soluble vitamin status is meaningfully influenced [89].

Therefore, alcohol permits ingredients to reveal their own unique flavors in ways that other liquids (like water or broth) or fats (like butter and olive oil) cannot. Wine alcohol evaporates while the food is cooking, and only the flavor remains. Boiling down wine concentrates the tastes/flavors, including acidity and sweetness. Like salt, alcohol brings out the flavor in food. Whether cooking with wine, beer or liquor, the alcohol in those beverages increases flavor perception in at least two important ways: by evaporation and by molecular bonding [83].

Table 3. Main chemical compounds in white and red wine.

\begin{tabular}{|c|c|c|c|}
\hline Compounds & Compounds & Typical Range & Reference \\
\hline \multirow{3}{*}{ Sugars } & Glucose (g/L) & $0.2-0.8$ (dry) $*$ up to 30 (sweet) & [90] \\
\hline & Fructose $(\mathrm{g} / \mathrm{L})$ & 1-2 (dry), up to 60 (sweet) & [90] \\
\hline & Residual sugar & $<1.5$ (dry) & [58] \\
\hline \multirow{8}{*}{ Alcohols } & Ethyl alcohol (g/L) & $72-120(9.1-15.1 \% \mathrm{v} / \mathrm{v})$ & [90] \\
\hline & & 12.5-14.5 (red wine) & [91] \\
\hline & & $5-15$ & [90] \\
\hline & Glycerol (g/L) & 10 (red wine) & [58] \\
\hline & & $\sim 7$ (white wine) & [58] \\
\hline & Butan,2,3-diol (g/L) & $0.3-1.5$ & [90] \\
\hline & Inositol (g/L) & $0.2-0.7$ & [90] \\
\hline & Sorbitol (g/L) & 0.1 & [90] \\
\hline \multirow{4}{*}{ Acids } & & $3.5-15.0$ & [90] \\
\hline & Total (g/L) & $5.5-8.5$ & [58] \\
\hline & & $4.75-7.5$ (red wine) & [91] \\
\hline & Acetic $(\mathrm{g} / \mathrm{L})$ & $0.5-1.0$ & [90] \\
\hline \multirow{4}{*}{ Metal cations } & Potassium (g/L) & $0.5-1.5$ & [90] \\
\hline & Sodium (g/L) & $0.03-0.05$ & [90] \\
\hline & Magnesium (g/L) & $0.05-0.15$ & [90] \\
\hline & Calcium $(\mathrm{g} / \mathrm{L})$ & $0.05-0.15$ & [90] \\
\hline Aromatic compounds & Total $(\mathrm{g} / \mathrm{L})$ & $0.8-1.2$ & [58] \\
\hline \multirow{2}{*}{$\mathrm{pH}$} & & 3.1-3.4 (white wine) & [58] \\
\hline & & 3.3-3.9 (red wine) & {$[58,91]$} \\
\hline Total phenols & Total (mg GAE/L) & $190-1300$ & [58] \\
\hline \multirow{3}{*}{ Non-flavonoids } & Total (mg GAE/L) & $160-500$ & [58] \\
\hline & Cinnamates, derivatives (mg GAE/L) & $130-165$ & [58] \\
\hline & Low volatility benzene derivatives (mg GAE/L) & $10-60$ & [58] \\
\hline \multirow{20}{*}{ Flavonoids } & Total flavonoids (mg GAE/L) & $25-1060$ & [58] \\
\hline & Total polyphenol index & 16.6-65.7 (red wine) & [91] \\
\hline & Catechins (mg GAE/L) & $15-200$ & [58] \\
\hline & Flavanols (mg GAE/L) & Trace- 50 & [58] \\
\hline & Anthocyanins (mg GAE/L) & 20-200 (red wine) & [58] \\
\hline & Total anthocyanins (mg/L) & $113.5-442.5$ & [91] \\
\hline & Total monomeric anthocyanins (mg/L) & $1.1-2.4$ & [91] \\
\hline & Total tannins $(\mathrm{g} / \mathrm{L})$ & $13.85-252.82$ & [91] \\
\hline & Monomeric flavanols (mg/L) & 3.5-30.4 (red wine) & [37] \\
\hline & Total proanthocyanidins (mg/L) & 193.3-1230.6 (red wine) & [37] \\
\hline & Total proanthocyanidins (mDP) & $4.5-6.2$ (red wine) & [37] \\
\hline & Total proanthocyanidins (\%gal) & 3.6-6.5 (red wine) & [37] \\
\hline & Total proanthocyanidins (\%prodeph) & 13.7-21.6 (red wine) & [37] \\
\hline & Oligomeric proanthocyanidins (mg/L) & 22.1-228.3 (red wine) & [37] \\
\hline & Oligomeric proanthocyanidins (mDP) & 3.7-5.0 (red wine) & {$[92,93]$} \\
\hline & Oligomeric proanthocyanidins (\%gal) & $1.8-3.3$ (red wine) & {$[92,93]$} \\
\hline & Polymeric proanthocyanidins (mg/L) & 261.3-1002.3 (red wine) & [37] \\
\hline & Polymeric proanthocyanidins (mDP) & 6.9-22.1 (red wine) & [92-94] \\
\hline & Polymeric proanthocyanidins (\%gal) & $2.8-8.3$ (red wine) & [92-94] \\
\hline & Polymeric Proanthocyanidins (\%prodeph) & $8.2-11.3$ (red wine) & [94] \\
\hline
\end{tabular}

${ }^{*}$ EU definition of 'dry', < 9 g/L sugar; mDP, mean degree of polymerization; \%gal, percentage of galloylation;

\%prodeph, percentage of prodelphinidins. 
However, at the same time that alcohol itself can be an asset when cooking with it, it can also be a liability. Alcohol has its own pungent qualities, and these qualities are heightened and can become harsh in hot foods. Cooks may therefore boil sauces for some time to evaporate off as much alcohol as possible. Moreover, one concern when cooking with alcoholic beverages is the concentration of ethanol in the cooked dish. This is important when serving the food to pregnant women, children and drivers and to anyone who wants to control their alcohol intake strictly. Recently, a few studies have been published on this subject $[95,96]$ giving some insight into ethanol loss during cooking.

For instance, in a flambé, from the French for "to flame," the heated vapors of spirits and high-alcohol wines are ignited into flickering, ghostly blue flames to burn off the alcohol and give a lightly singed flavor to a dish. Nevertheless, none of these practices leave a food free of alcohol. Trials have shown that long simmered stews retain about $5 \%$ of the initially added alcohol, briefly cooked dishes from 10-50\% and flambés as much as 75\% [18].

Moreover, Augustin and coworkers, in 1992 [97], published a paper entitled "Alcohol retention in food preparation", and they found out that it is not possible to remove all of the alcohol from a wine-based sauce, except if the sauce is cooked to dryness. These scientists found that anywhere from $4-85 \%$ of the alcohol remained in various dishes cooked with wine or liquor. The quantity of alcohol remaining is significantly influenced by the cooking temperature and time [98]. In their article, Augustin et al. [97] refer to some interesting examples with some interesting cooked dishes: pot roast Milano made with Burgundy retained only $4-6 \%$ of the alcohol after simmering at $85{ }^{\circ} \mathrm{C}$ for $2.5 \mathrm{~h}$, while orange chicken Burgundy retained 10-60\% of the alcohol after simmering at the same temperature for ten minutes. Cherry jubilee made with brandy retained $77-78 \%$ of the alcohol after flaming for only $48 \mathrm{~s}$ [97].

A question remains: Why in a cooked dish does the alcohol, which boils at $78{ }^{\circ} \mathrm{C}$, not evaporate from a sauce considerably faster than the water, which boils at $100^{\circ} \mathrm{C}$ ? Chemically, alcohol and water have a strong attraction to each other. In ethyl alcohol, the oxygen and hydrogen atoms have an affinity for the water molecules' hydrogen and oxygen atoms due to electrostatic attraction. The electrostatic force between an oxygen and hydrogen atom is called a hydrogen bond [99]. This attraction is strong enough to produce what is known as an "azeotropic mixture" when alcohol and water are mixed. When the mixture is heated to boiling, the first vapor that is formed contains generally alcohol, since it boils at a lesser temperature than water. However, as the hydrogen bonds form between molecules of alcohol and water, there will always be some higher boiling water molecules carried along with the molecules of alcohol even when the mixture begins to boil. After the mixture has boiled for some time and has been reduced in volume, there will permanently be some alcohol molecules remaining in the mixture due to the strong attraction between alcohol and water molecules. Towards the end, both the vapor and the mixture, in the pan, will consist of mostly water and about $5 \%$ of the alcohol originally added to the mixture [100].

Besides wine, other alcoholic beverages have been tested in culinary dishes. In order to evaluate the possibility as a cooking alcohol and tenderizing ingredients, kiwi wine and liqueur were added to braising mackerel and beef. Results showed that the crude proteolytic enzyme activity was high in kiwi wine (91\%) and liqueur (88\%). The trimethylamine (TMA) content in braising mackerel was $4.80 \mathrm{mg}$ in the kiwi wine group and $5.79 \mathrm{mg}$ in the kiwi liqueur group. The sensory test of boiled mackerel gained a high score in the kiwi wine and liqueur stews compared with the control group. The tenderizing effect on beef was high in the kiwi wine and liqueur groups compared with the control group. Thus, kiwi wine and liqueur could be used as cooking alcohol [101].

\subsubsection{Tannins and Acids: Astringency and Sourness}

Tannins affect the texture of a wine. In the mouth, they present as a drying sensation. Astringency, also known as the sensation of dryness, detectable throughout the oral cavity, may be due to a complexing reaction between phenolic compounds and proteins of the mouth and saliva [102]. High-molecular-weight phenolic compounds have long been viewed as antinutrients since they affect protein absorption or reduce iron availability, they complex with proteins, starches, and digestive 
enzymes and are thought to reduce the nutritional value of foods [103]. Tannins present in wine come from the grapes' skins, stems and seeds $[37,104]$.

When cooking with wine, the wine tannins become attracted to meat proteins rather than the proteins in our saliva, which makes the wine appear like a softer experience in the mouth [105]. According to Joachim and Schloss [83], when making a sauce with Cabernet Sauvignon, the tannins become concentrated as the sauce reduces. If the sauce does not also contain sufficient protein and fat to counterweight the tannin, the sauce could taste astringent. A vegetarian sauce, then, might work better with a less tannic red wine, like Pinot Noir, or a white wine [83].

Acidity/sourness is another chemical and sensory component that must be taking into account when cooking with wine. When experiencing the pairing of a tomato sauce with a red wine like Merlot, the acid in the tomatoes can burn right through the wine, making it seem flat. What is the cause? Merlot, which is typically on the low end in acid, cannot compete with the acid in the tomatoes. A Classic Chianti, made of Sangiovese grapes, on the other hand, is a terrible choice for tomato-based pasta dishes, because the Sangiovese grapes have too much acidity and will increase the acid sensation in the tomato sauce [105].

\subsubsection{Aromatic and Flavor Compounds: Flavors and Aromas}

Humans experience the presence of alcohol in a food through the senses of taste, smell and touch. The alcohol molecule bears some resemblance to a sugar molecule, and indeed, it has a slightly sweet taste. At high concentrations, alcohol is irritating and produces a pungent, "hot" sensation in the mouth, as well as in the nose [16]. As a volatile compound, alcohol has its own characteristic aroma. Its chemical compatibility with other volatile compounds means that concentrated alcohol tends to fix volatile compounds in foods and drinks and inhibit their release into the air. However, at very low concentrations, around 1\% (v/v) or less, alcohol actually improves the release of fruity esters and other volatile molecules into the air [17].

According to Harrington [105], if we want to make a dish that has one or two main flavors, it is worth thinking about wines that share those basic taste characteristics. Pinot Noir, for example, mainly Pinot Noir from Burgundy, is recognized for having flavors and aromas of mushrooms; it might pair well with a dish that features many fresh, sautéed mushrooms. A bright dish with a finishing splash of lemon juice might answer well to a wine with a fine, bright citrus flavor, like Sauvignon Blanc. Cream sauces with shrimp will likely match up well with a creamy, buttery Chardonnay [105].

However, some authors state that the aroma of wine is less important when selecting a wine for cooking; they state that there are non-volatile compounds of red wine that are important for meat stock preparation and that the preparation technique affects the taste/flavor of meat stock reduction when prepared with red wine [106].

\subsubsection{Visual and Mouthfeel Sensations: Colors and Textures}

Color is the first notable characteristic of a food and often predetermines or "colors" our expectation. We use color as a way to identify a food and to judge his quality [107]. Sometimes, cooks use organic acids imbedded in organic solutions such as vinegar, wine and beer to perform acidic marination. In this way, they enhance the flavor and tenderness of meat prior to cooking. The tenderizing action of acidic marinades is due to the low $\mathrm{pH}$ during cooking (weakening of meat structures due to swelling of the meat, increased proteolysis by cathepsins and increased conversion of collagen to gelatin) [108]. Moreover, the shelf life of the meat may be positively affected by this process due to the acidic or alkaline nature of the solution and the antimicrobial and antioxidant activity of some marinade additives such us red wines [109,110]. However, if red wine is used, color changes may occur in the final dish, which may or may not be pleasant for the consumer.

Red wine is rich in anthocyanins that give rise to the blue-purple-red-orange colors. Anthocyanins, carrying a net-charge and being glycosylated, are highly water-soluble. Anthocyanins span quite a range of color hues. An increasing number of hydroxyl groups yields a more bluish color, whereas 
methoxy groups give a more red color. Thus, pelargonidin is orange, whereas delphinidin and malvidin are purple. The color also changes with $\mathrm{pH}$. At a $\mathrm{pH}$ of around three, the anthocyanins are most strongly colored, exhibiting their well-known purple-red color. At $\mathrm{pH}$ 5, anthocyanins turn almost colorless, and at neutral and alkaline $\mathrm{pH}$, the color goes from blue to green. Another factor contributing to color shade is copigmentation, a phenomenon by which some compounds may cause a red-shift of the anthocyanin absorption and, hence, give a more bluish color and a concomitant increase in absorption. Phenolic compounds like flavonoids and cinnamic acids are particularly effective at this [111,112].

Istrati et al. [1] found that the action of dry red wine-based marinades with the addition of spices and seasonings on myofibrillar proteins results in tenderization of bovine biceps femoris muscle without negative effects on meat color. However, this is not a new subject. According to Hervé [113], in 1995, Okuda and Ueda extended this study by analyzing samples of beef that were boiled after having been marinated in wine (white and red) and in solutions containing only certain components of wine. The samples used were marinated for three days and then boiled for ten minutes. The outer and inner parts of the samples were analyzed separately. The water content and mass of the samples marinated in red wine were slightly greater than those of the samples marinated in white wine, but the masses of dry matter were about the same. In other words, red wine marinades did a better job of preserving the tenderness of the meats. Moreover, these authors also found that red wine marinades also did a better job of tenderizing the meats; both the inner and outer parts of the samples were more tender than the ones marinated in white wine and also more tender than samples cooked without having been marinated. Because red wine polyphenols react chemically with proteins, Okuda and Ueda also tested their effect by marinating the same meats in trial solutions containing fixed concentrations of tannic acid (representing the polyphenols), organic acids and ethanol. Solutions composed of water, ethanol and organic and tannic acids (similar composition with a red wine) modified the meat in the same way as red wine alone. It appears that proteins react with the polyphenols found in red wines in such a way as to seal the juices of the meat by hardening, or encrusting, its surface [113].

In Figure 7 are some examples of dishes cooked with wine or using wine as a main ingredient.

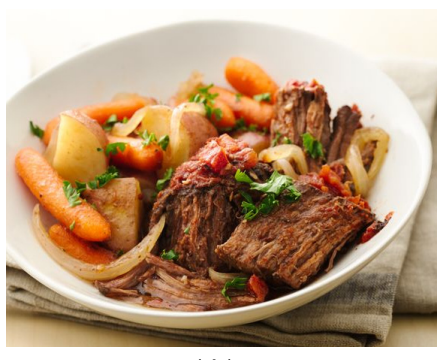

(A)

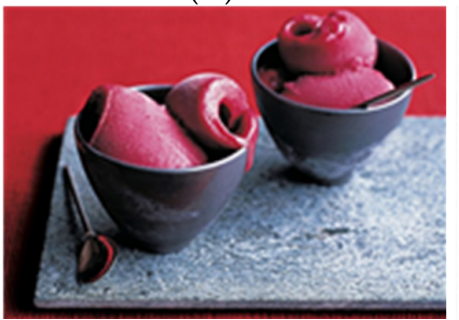

(D)

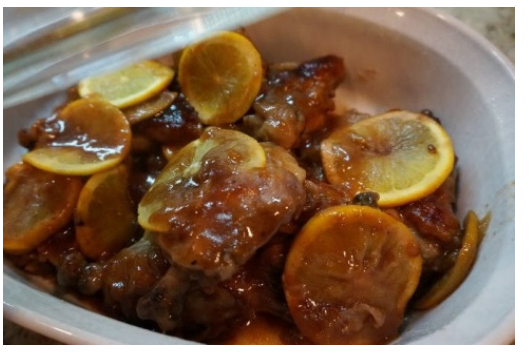

(B)

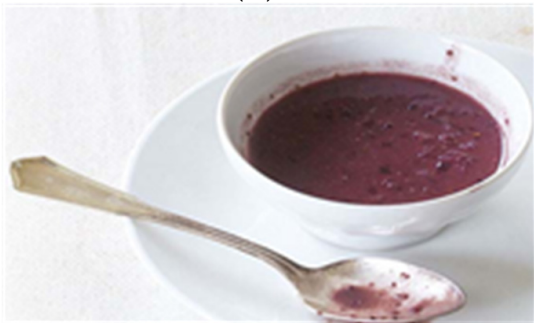

(E)

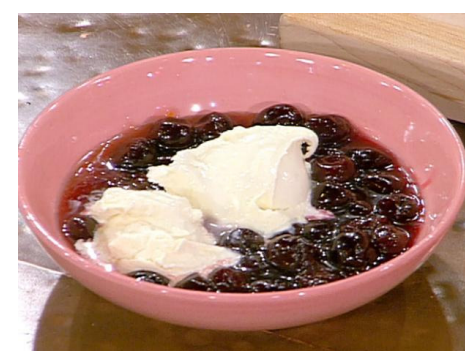

(C)

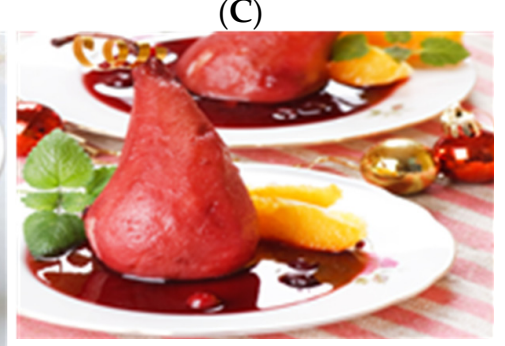

(F)

Figure 7. Pot roast Milano made with Burgundy (A); orange chicken Burgundy (B) cherry jubilee made with brandy accompanied by sour cream $(\mathbf{C})$; a great-colored sorbet made with ripe plums and red wine (D); red wine pan sauce (E) and a wine poached pear $(\mathbf{F})$.

\section{Final Remarks}

Cooking with wine or vine products is an adventure, and at the table during the meal, similarities and contrasting characteristics can be found in components such as texture, flavors and aromas. 
The use of wine in cooking has the purpose of adding flavor and changing the food's texture, as well as the aromatic dimension provided by ethanol and other wine volatiles. Nevertheless some considerations must be taken into account in that some wine qualities can be problematic in the kitchen, like the astringency and bitterness of red wine.

Vine leaves have been used in some cultures since prehistoric times. They can be used fresh from the vine in late spring and early summer. Moreover, sarma may be accompanied by wine made from the same grapes, as the leaves will enhance and have some of the flavors of the grapes.

Beside all of this, grapes are considered as a rich source of phenolic compounds, and cooks can take advantage of their natural sweetness to produce jams, grape juices, jellies and a plethora of dishes including some salty ones, thus making desserts and main courses awesome culinary and sensory experiences.

Acknowledgments: This work is supported by: European Investment Funds by FEDER/COMPETE/POCIOperacional Competitiveness and Internacionalization Programme, under Project POCI-01-0145-FEDER-006958 and National Funds by FCT - Portuguese Foundation for Science and Technology, under the project UID/AGR/04033/2013 and by the Chemical Research Center (CQ-UTAD). Additional thanks to the Projet NORTE-01-0145-FEDER-000038 (I\&D INNOVINE\&WINE - Innovation Platform of Vine \& Wine).

Conflicts of Interest: The authors declare no conflict of interest.

\section{References}

1. Istrati, D.; Ciuciu, A.-M.S.; Vizireanu, C.; Ionescu, A.; Carballo, J. Impact of spices and wine-based marinades on tenderness, fragmentation of myofibrillar proteins and color stability in bovine biceps femoris muscle. J. Texture Stud. 2015, 46, 455-466. [CrossRef]

2. Harrington, R.J. Defining gastronomic identity-The impact of environment and culture on prevailing components, texture and flavors in wine and food. J. Culin. Sci. Technol. 2005, 4, 129-152. [CrossRef]

3. Plotnik, R.; Kouyoumdjian, H. Introduction to Psychology, 9th ed.; Cengage Learning: HPB-California (Dallas, TX, USA), 2011.

4. Alija, J.; Talens, C. New concept of desserts with no added sugar. Int. J. Gastron. Food Sci. 2012, 1, 116-122. [CrossRef]

5. Threlfall, R.T.; Morris, J.R.; Howard, L.R.; Brownmiller, C.; Walker, T.L. Pressing effects on yield, quality, and nutraceutical content of juice, seeds, and skins from black beauty sunbelt grapes. J. Food Sci. 2005, 70, 167-171. [CrossRef]

6. Hardie, W.J.; O'Brien, T.P.; Jaudzems, V.G. Morphology, anatomy and development of the pericarp after anthesis in grape, Vitis Vinifera L. Aust. J. Grape Wine Res. 1996, 2, 97-142. [CrossRef]

7. Peynaud, E.; Ribéreau-Gayon, P. Chapter 4: The grape. In The Biochemistry of Fruits and Their Products; Hulme, A.C., Ed.; Academic: London, UK, 1971; Volume 2.

8. Sat, I.G.; Sengul, M.; Keles, F. Use of grape leaves in canned food. Pak. J. Nutr. 2002, 1, 257-262.

9. Schneider, E.; von der Heydt, H.; Esperester, A. Evaluation of polyphenol composition in red leaves from different varieties of Vitis vinifera. Planta Med. 2008, 74, 565-572. [CrossRef] [PubMed]

10. Karabourniotis, G.; Bornman, J.F.; Nikolopoulos, D. A possible optical role of the budle sheath extensions of the heterobaric leaves of Vitis vinifera and Quercus coccifera. Plant Cell Environ. 2000, 23, 423-430. [CrossRef]

11. Vivier, M.A.; Pretorius, I.S. Genetic Improvement of Grapevine: Tailoring Grape Varieties for the Third Millennium-A Review. S. Afr. J. Enol. Vitic. 2000, 21, 5-26.

12. Botelet, A. The Gourmet's Guide to Cooking with Wine; Quarry Books: Beverly, MA, USA, 2008.

13. La France, P. Cooking and Eating with Beer, 50 Chefs, Brew Masters, and Restaurateurs Talk about Beer and Food; John Wiley \& Sons: New York, NY, USA, 1997.

14. Kennedy, J.A. Grape and wine phenolics: Observations and recent findings. Cienc. Investig. Agrar. 2008, 35, 107-120. [CrossRef]

15. Cho, S.-M.; Kim, J.-H.; Park, H.-J.; Chun, H.-K. Manufacturing of Korean traditional rice wine by using Gardenia jasminoides. Korean J. Microbiol. Biotechnol. 2009, 37, 413-415.

16. Vilela, A.; Inês, A.; Cosme, F. Is wine savory? Umami taste in wine. SDRP J. Food Sci. Technol. 2016, 1, 1-6. Available online: http://hdl.handle.net/10348/5661 (accessed on 9 August 2017). 
17. Jordão, A.M.; Vilela, A.; Cosme, F. From Sugar of Grape to Alcohol of Wine: Sensorial Impact of Alcohol in Wine. Beverages 2015, 1, 292-310. [CrossRef]

18. McGee, H. On Food and Cooking: The Science and Lore of the Kitchen; Scribner: New York, NY, USA, $2004 ;$ p. 884. ISBN 1-4165-5637-0.

19. Liu, H.F.; Wu, B.H.; Fan, P.G.; Li, S.H.; Li, L.S. Sugar and acid concentrations in 98 grape cultivars analyzed by principal component analysis. J. Sci. Food Agric. 2006, 86, 1526-1536. [CrossRef]

20. Robinson, S.P.; Davies, C. Molecular biology of grape berry ripening. Aust. J. Grape Wine Res. 2000, 6, $175-188$. [CrossRef]

21. Kanellis, A.K.; Roubelakis-Angelakis, K.A. Grape. In Biochemistry of Fruit Ripening; Seymour, G., Taylor, J., Tucker, G., Eds.; Chapman \&Hall: London, UK, 1993; pp. 189-234.

22. Lamikanra, O.; Inyang, I.D.; Leong, S. Distribution and Effect of Grape Maturity on Organic Acid Content of Red Muscadine Grapes. J. Agric. Food Chem. 1995, 43, 3026-3028. [CrossRef]

23. Kliewer, W.M. Sugars and Organic Acids of Vitis vinifera. Plant Physiol. 1966, 41, 923-931. [CrossRef] [PubMed]

24. Wermelinger, B. Nitrogen Dynamics in Grapevine. Physiology and Modeling. In Proceedings of the International Symposium on Nitrogen in Grapes and Wine, Seatle, WA, USA, 18-19 June 1991; Rantz, J.M., Ed.; American Society for Enology and Viticulture: Davis, CA, USA, 1991; pp. 23-31.

25. Huang, Z.; Ough, C.S. Amino acid profiles of commercial grape juices and wines. Am. J. Enol. Vitic. 1991, 42, 261-267.

26. Hernandez-Orte, P.; Ibraz, M.J.; Cacho, J.; Ferriera, V. Amino acid determination in grape juices and wines by HPLC using a modification of the 6-aminoquinolyl-nhydroxysuccinimidyl carbamate (AQC) method. Chromatographia 2003, 58, 29-35.

27. Lorrain, B.; Chira, K.; Teissedre, P.-L. Phenolic composition of Merlot and Cabernet-Sauvignon grapes from Bordeaux vineyard for the 2009-vintage: Comparison to 2006, 2007 and 2008 vintages. Food Chem. 2011, 126, 1991-1999. [CrossRef] [PubMed]

28. Jordão, A.M.; Ricardo-da-Silva, J.M.; Laureano, O. Evolution of catechins and oligomeric procyanidins during grape maturation of Castelão Francês and Touriga Francesa. Am. J. Enol. Vitic. 2001, 53, 231-234.

29. Pozo-Bayon, M.A.; Hernandez, M.T.; Martin-Alvarez, P.J.; Polo, M.C. Study of low molecular weight phenolic compounds during the aging of sparkling wines manufactured with red and white grape varieties. J. Agric. Food Chem. 2003, 51, 2089-2095. [CrossRef] [PubMed]

30. Vanhoenacker, G.; De Villiers, A.; Lazou, K.; Keukeleire, D.; Sandra, P. Comparison of high performance liquid chromatography-Mass spectroscopy and capillary electrophoresis-Mass spectroscopy for the analysis of phenolic compounds in diethyl ether extracts of red wines. Chromatographia 2001, 54, 309-315. [CrossRef]

31. Hernandez-Jimenez, A.; Gomez-Plaza, E.; Martinez-Cutillas, A.; Kennedy, J.A. Grape skin and seed proanthocyanidins from Monastrell x Syrah grapes. J. Agric. Food Chem. 2009, 57, 10798-10803. [CrossRef] [PubMed]

32. Cheynier, V.; Rigaud, J. HPLC separation and characterization of flavonols in the skins of Vitis Vinifera var. Cinsault. Am. J. Enol. Vitic. 1986, 37, 248-252.

33. Pastrana-Bonilla, E.; Akoh, C.C.; Sellappan, S.; Krewer, G. Phenolic content and antioxidant capacity of Muscadine grapes. J. Agric. Food Chem. 2003, 51, 5497-5503. [CrossRef] [PubMed]

34. Alcalde-Eon, C.; Escribano-Bailon, M.T.; Santos-Buelga, C.; Rivas Gonzalo, J.C. Changes in the detailed pigment composition of red wine maturity and ageing-A comprehensive study. Anal. Chem. Acta 2006, 563, 238-254. [CrossRef]

35. Vidal, S.; Hayasaka, Y.; Meudec, E.; Cheynier, V.; Skouroumounis, G. Fractionation of grape anthocyanin classes using multilayer coil countercurrent chromatography with step gradient elution. J. Agric. Food Chem. 2004, 52, 713-719. [CrossRef] [PubMed]

36. De Pascual-Teresea, S.; Rivas-Gonzalo, J.C.; Santos-Buelga, C. Prodelphinidins and related flavanols in wine. Int. J. Food Sci. Technol. 2000, 35, 33-40. [CrossRef]

37. Cosme, F.; Ricardo-da-Silva, J.M.; Laureano, O. Tannic profiles of Vitis vinifera L. cv. red grapes growing in Lisbon and from their monovarietal wines. Food Chem. 2009, 112, 197-204. [CrossRef] 
38. Mane, C.; Souquet, J.M.; Olle, D.; Verries, C.; Veran, F.; Mazerolles, G.; Cheynier, V.; Fulcrand, H. Optimization of simultaneous flavanol, phenolic acid, and anthocyanin extraction from grapes using an experimental design: Application to the characterization of Champagne grape varieties. J. Agric. Food Chem. 2007, 55, 7224-7233. [CrossRef] [PubMed]

39. Williams, P.J.; Strauss, C.R.; Wilson, B. Hydroxylated linalool derivatives of volatile monoterpenes of Muscat grapes. J. Agric. Food Chem. 1980, 28, 766-771. [CrossRef]

40. Allen, M.S.; Lacey, M.J. Methoxypyrazine grape flavor components: Influence of grape cultivarescultivars. In Proceedings of the Eighth Australian Wine Industry Technical Conference, Melbourne, Australia, 25-29 October 1992; Stockley, C.S., Johnstone, R.S., Leske, P.A., Lee, T.H., Eds.; Winetitles: Adelaide, Australia, 1992; p. 1995.

41. Sabir, A.; Kafkas, E.; Tangolar, S. Distribution of major sugars, acids and total phenols in juice of five grapevine (Vitis spp.) cultivars at different stages of berry development. Span. J. Agric. Res. 2010, 8, 425-433. [CrossRef]

42. Aubert, C.; Chalot, G. Chemical composition, bioactive compounds, and volatiles of six table grape varieties (Vitis vinifera L.). Food Chem. 2017. [CrossRef]

43. Balìk, J.; Kyseláková, M.; Vrchotová, N.; Triska, J.; Kumsta, M.; Veverka, J.; HÍc, P.; Totusek, J.; Lefnerová, D. Relations between polyphenols content and antioxidant activity in vine grapes and leaves. Czech J. Food Sci. 2008, 26, S25-S32.

44. Mikes, O.; Vrchotová, N.; Triska, J.; Kyseláková, M.; Smidrkal, J. Distribution of major polyphenolic compounds in vine grapes of different cultivars growing in South Moravian vineyards. Czech J. Food Sci. 2008, 26, 182-189.

45. Pérez-Trujillo, J.P.; Hernández, Z.; López-Bellido, F.J.; Hermosín-Guiteérrez, L. Characteristic phenolic composition of single-cultivar red wines of the Canary Islands (Spain). J. Agric. Food Chem. 2011, 59, 6150-6154.

46. Montalegre, R.R.; Peces, R.R.; Vozmediano, J.L.S.; Gascueña, J.M.; Romero, E.G. Phenolic compunds in skins and seeds of ten grape Vitis vinifera varieties grown in a warm climate. J. Food Compos. Anal. 2006, 19, 687-693. [CrossRef]

47. Mateus, N.; Marques, S.; Gonçalves, A.C.; Machado, J.M.; De Freitas, V.A.P. Proanthocyanidin composition of red Vitis vinifera varieties from the Douro Valley during ripening: Influence of cultivation altitude. Am. J. Enol. Vitic. 2001, 52, 115-121.

48. De Freitas, V.A.P.; Glories, Y.; Monique, A. Developmental changes of procyanidins in grapes of red Vitis vinifera varieties and their composition in respective wine. Am. J. Enol. Vitic. 2000, 51, 397-403.

49. De Freitas, V.A.P.; Glories, Y. Concentration and compositional changes of procyanidines in grape seeds and skin of white Vitis vinifera varieties. J. Sci. Food Agric. 1999, 79, 1601-1606. [CrossRef]

50. Torregrosa, L.; Vialet, S.; Adivèze, A.; Iocco-Corena, P.; Thomas, M.R. Grapevine (Vitis vinifera L.). Methods Mol. Biol. 2015, 1224, 177-194. [CrossRef] [PubMed]

51. Keller, M. The Science of Grapevines: Anatomy and Physiology, 2nd ed.; Academic Press: Tokyo, Japan, 2015; pp. 1-57.

52. Fontes, N.; Gerós, H.; Delrot, S. Grape Berry Vacuole: A Complex and Heterogeneous Membrane System Specialized in the Accumulation of Solutes. Am. J. Enol. Vitic. 2011, 62, 270-278. [CrossRef]

53. Conde, C.; Silva, P.; Fontes, N.; Dias, A.C.P.; Tavares, R.M.; Sousa, M.J.; Agasse, A.; Delrot, S.; Gerós, H. Biochemical changes throughout grape berry development and fruit and wine quality. Food 2007, 1, 1-22.

54. Rosa, E. Os Problemas Causados à Saúde Pelas Reações de Oxidação. Available online: http://rede. novaescolaclube.org.br/planos-de-aula/os-problemas-causados-saude-pelas-reacoes-de-oxidacao (accessed on 30 July 2017).

55. Agrisoil Research. Uva da Tavola e Apirenia: Un Binomio Naturale. Available online: http://www. freshplaza.it/article/13924/Uva-da-tavola-e-apirenia-un-binomio-naturale (accessed on 30 July 2017).

56. Ribéreau-Gayon, P.; Dubourdieu, D.; Donèche, B.; Lonvaud, A. The Microbiology of Wine and Vinifications, 1st ed.; Handbook of Enology; Wiley: Chichester, UK, 2000; Volume 1.

57. Wilson, B.; Strauss, C.R.; Williams, P.J. The distribution of free and glycosidically-bound monoterpenes among skin, juice and pulp fractions of some white grape varieties. Am. J. Enol. Vitic. 1986, 37, 107-111.

58. Jackson, R.S. Wine Science: Principles and Applications, 3rd ed.; Elsevier: San Diego, CA, USA, 2008. 
59. Schlosser, J.N.; Olsson, M.; Weis, K.; Reid, F.; Peng, S.; Lund, P.B. Cellular expansion and gene expression in the developing grape (Vitis vinifera L.). Protoplasma 2008, 232, 255-265. [CrossRef] [PubMed]

60. Roth, I. Fruits of the Angiosperms; Gebrüder Bornträger: Berlin, Germany, 1977.

61. Vilela, A.; Cosme, F. Drink Red: Phenolic Composition of Red Fruit Juices and Their Sensorial Acceptance. Beverages 2016, 2, 29. [CrossRef]

62. Falcão, A.P.; Chaves, E.S.; Falcão, L.D.; Gauche, C.; Barreto, P.L.M.; Bordignon-Luiz, M.T. Rheological behavior and color stability of anthocyanins from Merlot (Vitis vinifera L.) and Bordô (Vitis labrusca L.) grapes in a jam model system. Ciênc. Tecnol. Aliment. 2009, 29, 857-862. [CrossRef]

63. Pop, I.M.; Pascariu, S.M.; Simeanu, D. The grape pomace influence on the broiler chickens growing rate. Lucrari Stiintifice Seria Zootehnie 2015, 64, 34-39.

64. Oganesyants, L.; Panasyuk, A.; Kuzmina, H. Study of features of the biochemical composition of red vine leaves of autochthonous varieties in Russia. BIO Web Conf. 2015, 5. [CrossRef]

65. Katalinic, V.; Generalic, I.; Skroza, D.; Ljubenkov, I.; Teskera, A.; Konta, I.; Boban, M. Insight in the phenolic composition and antioxidative properties of Vitis vinifera leaves extracts. Croat. J. Food Sci. Technol. 2009, 1, 7-15.

66. Güler, A.; Candemir, A. Total Phenolic and Flavonoid Contents, Phenolic Compositions and Color Properties of Fresh Grape Leaves Turkish. J. Agric. Nat. Sci. 2014, 1, 778-782.

67. Radovanović, B.; Andjelković, M.; Radovanović, V.; Milenković-Andjelković, A.; Đekić, S. Polyphenols and Antioxidant Activity of Different Vinegrape Leaves. Zbornik Radova 2015, 20, 347-352.

68. Dani, C.; Oliboni, L.S.; Agostini, F.; Funchal, C.; Serafini, L.; Henriques, J.; Salvador, M. Phenolic content of grapevine leaves (Vitis labrusca var. Bordo) and its neuroprotective effect against peroxide damage. Toxicol. In Vitro 2010, 24, 148-153. [CrossRef] [PubMed]

69. Fernandes, B.; Correia, A.C.; Cosme, F.; Nunes, F.M.; Jordão, A.M. Volatile components of vine leaves from two Portuguese grape varieties (Vitis vinifera L.), Touriga Nacional and Tinta Roriz, analysed by solidphase microextraction. Nat. Prod. Res. 2015, 29, 37-45. [CrossRef] [PubMed]

70. Gokturk, N.; Artlk, N.; Yavas, I.; Fidan, Y. Research on the possibilities of using leaves some grape varieties and rootstocks as canning purposes. Food 1997, 22, 15-23.

71. Terashima, I.; Hanba, Y.T.; Tholen, D.; Niinemets, Ü. Leaf functional anatomy in relation to photosynthesis. Plant Physiol. 2011, 155, 108-116. [CrossRef] [PubMed]

72. Koundouras, S.; Tsialtas, I.T.; Zioziou, E.; Nikolaou, N. Rootstock effects on the adaptive strategies of grapevine (Vitis vinifera L. cv. Cabernet-Sauvignon) under contrasting water status: Leaf physiological and structural responses. Agric. Ecosyst. Environ. 2008, 128, 86-96. [CrossRef]

73. Boso, S.; Gago, P.; Alonso-Villaverde, V.; Santiago, J.J.; Mendez, J.; Pazos, I.; Martínez, M.C. Variability at the electron microscopy level in leaves of members of the genus Vitis. Sci. Hortic. 2011, 128, 228-238. [CrossRef]

74. Monteiro, A.; Teixeira, G.; Lopes, C.M. Comparative leaf micromorphoanatomy of Vitis vinifera ssp. vinifera (Vitaceae) red cultivars. Ciênc. Téch. Vitivinic. 2013, 28, 19-28.

75. Mauseth, J.D. Botany: An Introduction to Plant Biology, 6th ed.; Jones and Bartlett Publishers: Burlington, MA, USA, 2017.

76. Salem-Fnayou, A.B.; Bouamama, B.; Ghorbel, A.; Mliki, A. Investigations on the Leaf Anatomy and Ultrastructure of Grapevine (Vitis vinifera) Under Heat Stress. Microsc. Res. Tech. 2011, 74, 756-762. [CrossRef] [PubMed]

77. Bolhar-Nordenkampf, H.R. Shoot morphology and leaf anatomy in relation to photosynthesis. In Tecniques in Bioproductivity and Photosynthesis, 2nd ed.; Coombs, J., Hall, D.O., Long, S.P., Scurlock, J.M., Eds.; Pergamon Press: Oxford, UK, 1987; pp. 107-117.

78. Pinto, T.M.; Anjos, M.D.R.; Martins, N.M.; Gomes-Laranjo, J.; Ferreira-Cardoso, J.; Peixoto, F. Structural analysis of Castanea sativa Mill. leaves from different regions in the tree top. Braz. Arch. Biol. Technol. 2011, 54, 117-124. [CrossRef]

79. Dogan, Y.; Nedelcheva, A.; Łuczaj, Ł.; Drăgulescu, C.; Stefkov, G.; Maglajlić, A.; Pieroni, A. Of the importance of a leaf: The ethnobotany of sarma in Turkey and the Balkans. J. Ethnobiol. Ethnomed. 2015, 11, 26. [CrossRef] [PubMed]

80. Yerasimos, M. 500 Years of Ottoman Cuisine [500 Yıllık Osmanlı Mutfă̆ı]; Boyut: Istanbul, Turkey, 2002. 
81. Monagas, M.; Hernandez-Ledesma, B.; Gomez-Cordovés, C.; Bartolomé, B. Commercial dietary ingredients from Vitis vinifera L. leaves and grape skins: Antioxidant and chemical characterization. J. Agric. Food Chem. 2006, 54, 319-327. [CrossRef] [PubMed]

82. Orhan, D.D.; Orhan, N.; Ozcelik, B.; Ergun, F. Biological activities of Vitis vinifera L. leaves. Turk. J. Biol. 2009, $33,341-348$.

83. Joachim, D.; Schloss, A. Alcohol's Role in Cooking. Fine Cook. 2017, 104, 28-29.

84. Da Porto, C.; Cordaro, F.; Marcassa, N. Effects of carbohydrate and noncarbohydrate sweeteners on the orange spirit volatile compounds. Food Sci. Technol. 2006, 39, 159-165. [CrossRef]

85. Dalton, P.; Doolittle, N.; Nagata, H.; Breslin, P.A.S. The merging of the senses: Integration of subthreshold taste and smell. Nat. Neurosci. 2000, 3, 431-432. [CrossRef] [PubMed]

86. Goldner, M.C.; Zamora, M.C.; di Leo Lira, P.; Gianninoto, H.; Bandoni, A. Effect of ethanol level in the perception of aroma attributes and the detection of volatile compounds in red wine. J. Sens. Stud. 2009, 24, 243-257. [CrossRef]

87. Pickering, G.J.; Heatherbell, D.A.; Vanhanen, L.P.; Barnes, M.F. The effect of ethanol concentration on the temporal perception of viscosity and density in white wine. Am. J. Enol. Vitic. 1998, 49, 306-318.

88. Fischer, U.; Noble, A.C. The effect of ethanol, catechin concentration, and $\mathrm{pH}$ on sourness and bitterness of wine. Am. J. Enol. Vitic. 1994, 45, 6-10.

89. Simonetti, P.; Cestaro, B.; Porrini, M.; Viani, P.; Roggi, C.; Testolin, G. Effect of alcohol intake on lipids and fat-soluble vitamins in blood. Minerva Med. 1993, 84, 447-452. [PubMed]

90. Clarke, R.J.; Bakker, J. Wine Flavour Chemistry; Blackwell Publishing: Oxford, UK, 2004.

91. Cristino, R.; Costa, E.; Cosme, F.; Jordão, M.A. General phenolic characterisation, individual anthocyanin and antioxidant capacity of matured red wines from two Portuguese Appellations of Origins. J. Sci. Food Agric. 2013, 93, 2486-2493. [CrossRef] [PubMed]

92. Sun, B.; Leandro, C.; Ricardo-da-Silva, J.M.; Spranger, I. Separation of grape and wine proanthocyanidins according to their degree of polymerization. Agric. Food Chem. 1998, 46, 1390-1396. [CrossRef]

93. Sun, B.; Spranger, I.; Roque-do-Vale, F.; Leandro, C.; Belchior, P. Effect of different winemaking technologies on phenolic composition in tinta miúda red wines. Agric. Food Chem. 2001, 49, 5809-5816. [CrossRef]

94. Monagas, M.; Gómez-Cordovés, C.; Bartolomé, B.; Laureano, O.; Ricardo-da-Silva, J.M. Monomeric, oligomeric, and polymeric flavan-3-ol composition of wines and grapes from Vitis vinifera L. Cv. Graciano, Tempranillo, and Cabernet Sauvignon. Agric. Food Chem. 2003, 51, 6475-6481. [CrossRef] [PubMed]

95. Hansen, C.E.; Kwasniewski, M.T.; Sacks, G.L. Decoupling the effect of heating and flaming on chemical and sensory changes during flambé cooking. Int. J. Gastron. Food Sci. 2012, 1, 90-95. [CrossRef]

96. Mateus, D.; Ferreira, I.M.; Pinho, O. Headspace SPME-GC/MS evaluation of ethanol retention in cooked meals containing alcoholic drinks. Food Chem. 2011, 126, 1387-1392. [CrossRef]

97. Augustin, J.; Augustin, E.; Cutrufelli, R.L.; Hagen, S.R.; Teitzel, C. Alcohol retention in food preparation. J. Am. Diet. Assoc. 1992, 92, 486-488. [PubMed]

98. Ryapushkina, J.; Skovenborg, E.; Astrup, A.; Risbo, J.; Bech, L.M.; Jensen, M.G.; Snitkjær, P. Cooking with beer: How much alcohol is left? Int. J. Gastron. Food Sci. 2016, 5, 17-26. [CrossRef]

99. Zachariasen, W.H. The liquid "structure" of methyl alcohol. J. Chem. Phys. 1935, 3, 158-161. [CrossRef]

100. Cunningham, E.; Marcason, W. Does the Alcohol Used in Cooking Burn Off Completely. J. Am. Diet. Assoc. 2002, 102, 536. [CrossRef]

101. Woo, S.M.; Choi, I.W.; Jeong, Y.J. Effect of kiwi wine and kiwi liqueur on sensory characteristics as cooking alcohol. Korean J. Food Preserv. 2006, 13, 519-552.

102. Vilela, A.; Jordão, A.M.; Cosme, F. Wine phenolics: Looking for a smooth mouthfeel. SDRP J. Food Sci. Technol. 2016, 1, 1-8. [CrossRef]

103. Noble, C.A. Bitterness in wine. Physiol. Behav. 1994, 56, 1251-1255. [CrossRef]

104. Jordão, A.M.; Ricardo-da-Silva, J.M.; Laureano, O. Evolution of proanthocyanidins in bunch stems during berry development (Vitis vinifera L.). Vitis 2001, 40, 17-22.

105. Harrington, R.J. Food and Wine Pairing. A Sensory Experience; John Wiley \& Sons, Inc.: Hoboken, NJ, USA, 2008; p. 322.

106. Snitkjær, P.; Risbo, J.; Skibsted, L.H.; Ebeler, S.; Heymann, H.; Harmon, K.; Frøst, M.B. Beef stock reduction with red wine-Effects of preparation method and wine characteristics. Food Chem. 2011, 126, 183-196. [CrossRef] 
107. Griffiths, J.C. Coloring Food and beverages. Food Technol. 2005, 59, 38-44.

108. Berge, P.; Ertbjerg, P.; Larsen, L.M.; Astruc, T.; Vignon, X.; Moller, A.J. Tenderization of beef by lactic acid injected at different times post mortem. Meat Sci. 2001, 57, 347-357. [CrossRef]

109. Tompkin, R.B.; McNamara, A.M.; Acuff, G.R. Meat and poultry products. In Compendium of Methods for the Microbiological Examination of Foods, 4th ed.; Downes, F.P., Ito, K., Eds.; APHA-American Public Health Association: Washington, DC, USA, 2001; pp. 463-472.

110. Kargiotou, C.; Katsanidis, E.; Rhoades, J.; Kontominas, M.; Koutsoumanis, K. Efficacies of soy sauce and wine base marinades for controlling spoilage of raw beef. Food Microbiol. 2011, 28, 158-163. [CrossRef] [PubMed]

111. Boulton, R. The Copigmentation of Anthocyanins and Its Role in the Color of Red Wine: A Critical Review. Am. J. Enol. Vitic. 2001, 52, 67-87.

112. Mortensen, A. Carotenoids and other pigments as natural colorants. Pure Appl. Chem. 2006, 78, $1477-1491$. [CrossRef]

113. Hervé, T. Molecular Gastronomy, Exploring the Science of Flavour; Ebook; Columbia University Press: New York, NY, USA, 2006.

(C) 2017 by the authors. Licensee MDPI, Basel, Switzerland. This article is an open access article distributed under the terms and conditions of the Creative Commons Attribution (CC BY) license (http:/ / creativecommons.org/licenses/by/4.0/). 